\title{
Environmental Soil Microbiology: A Novel Research-Oriented Laboratory Course for Undergraduate Students
}

\author{
Zeyana Al-Hashmi and Said S. Al-Ismaily*
}

Department of Soils, Water and Agricultural Engineering, Sultan Qaboos University, PO Box 34, Al Khoud 123, Sultanate of Oman

Received: April 15, 2013 / Accepted: May 17, 2013

\begin{abstract}
Laboratory courses have a central and distinctive role in science education. The need of improving laboratory curricular materials in environmental soil microbiology education is a must more than ever as due to the followings: (i) emerging of new types of soil biological problems associated with new manipulated environments, (ii) the intimacy of human, plants, and animals to soil microbial activities, and (iii) environmental soil-connected issues is the area of current research interests. We present a novel research-oriented laboratory course for undergraduates in soil science, according to the need of reforming the laboratory curriculum as called by the National Science Education Standards to advocate inquiry and cognitivity in teaching and learning. Our inquirybased environmental soil microbiology laboratory course provides a good pedagogical opportunity in promoting critical thinking, making predictions, proposing causative factors, and presenting consistent arguments to support a position through effective scientific writing. The novelty of our laboratory curriculum relies on the integration of three main components namely the "skill learning", "research experience", and "effective writing skills" which ultimately may help in optimizing students thinking performance towards research oriented mindset. The course is divided into two modules (I \& II), where in module I students are introduced to the basic principles and techniques in soil microbiology. As for module II, students are assigned a research project to enhance their critical thinking and develop their conceptual skills in designing an experiment, problem solving, gathering and analysis of data, and scientific writing. The unit content can be modified to suit other specific laboratory curriculums in other branches of natural science without loss of students learning efficiency or impact.

Key words: Critical thinking, Environmental soil microbiology, Undergraduate education, Skills, Inquiry-learning.
\end{abstract}

\section{Introduction}

Laboratories curricula are considered to have a central and distinctive role in science education (Hofstein \& Lunetta, 2004; Bruck and Towns, 2013). In order to bridge theory with practice several universities have made the laboratory session as an important companion for undergraduate programs where theory and practice can coalesce for students (Fennessy et al. 1992; Kotiw et al. 1999; Russell \& Weaver, 2008). Science laboratory is of benefit and becomes a meaningful learning experience only if students are given opportunities to learn research methods and techniques that will increase their ability in investigating scientific phenomena and their engagement in solving problems (Tobin, 1990; Hodson, 1993; Skoumios et al., 2013). However, some educators are seriously questioning and scrutinizing the pedagogical effectiveness of the laboratory courses in providing such opportunities to students (see, for example, Bates, 1978; Tobin, 1990; Mamlok-Naaman et al., 2012). Hodson (1990) has claimed laboratory classes to be unproductive and confusing since there are often given without any clearly thought-out purpose. This led The National Science Education Standards (National Research Council [NRC], 1996) and education literature (Lunetta, 1998; Bybee, 2000) to call for a reform of the laboratory curriculum in science teaching. This is especially true as due to the current "information explosion" on cognition and student's learning behavior (Bransford et al. 1999). In addition, laboratory work in undergraduate teaching is considered to play a potential role in advocating learning by inquiry; which the latter defined by the NRC (1996) as "Inquiry is a multifaceted activity that involves making observations; posing questions; examining books and other sources of information to see what is already known; planning investigations; reviewing what is already known in light of experimental evidence; using tools to gather, analyze, and interpret data; proposing answers, explanations, and predictions; and communicating the results. Inquiry requires identification of assumptions, use of critical and logical thinking, and consideration of alternative explanations". 
The National Science Education Standards (NRC, 1996) and also the 2061 project by the American Association for the Advancement of Science (AAAS, 1990) emphasized on the need for inquiry-type laboratories as the central to the achievement of scientific literacy. Studies, however, showed that most science professors design their laboratory sessions making connections between practice and theory through direct implementation of concepts (Gunstone \& White, 1981; Wilkinson \& Ward, 1997). Wilkinson and Ward (1997) made a 5-point Likert scale asking teachers to rank their perceptions on the purpose of conducting laboratory in science courses (e.g. "to gain practice at making accurate observations and interpreting them", "to help students understand theoretical parts of science", and "to make science more interesting and enjoyable through actual experience"). The study found that teachers ranked "to gain practice at making accurate observations and interpreting them" as one of the most important aims of the laboratory. Interestingly, "to give training in solving problems and conducting investigations" was ranked seventh out of the ten items by the teachers. Kotiw et al. (1999) reported that many biology-oriented laboratory courses are of a non-inquiry type and have a protocol-based approach that often failed to develop higher academic skills such as hypothesizing, design and problem solving.

Designing inquiry-based environmental soil microbiology laboratories is specifically challenging due to the diverse and interrelated nature of the subject matter (Fennessy et al. 1992) adding to the multiple functions of soil and its interdependence with the surrounding environment (Yli-Halla, 2006). The need of providing, developing, or improving laboratory curricular materials in environmental soil microbiology education is a must more than ever as there are new types of problems associated with new manipulated and/or emerging environments. We have also learned much about the vast numbers and varieties of soil microbes, amidst which are now valued for their potential to help solving environmental problems (Hopmans, 2007; Lin, 2006). ). Hartemink and McBratney (2008) stated that soil biology continues to be "hot" in soil science as they have showed the impact factor of Soil Biology and Biochemistry (impact factor $=3.5$; year 2013) to be higher than that of more generic journals like European Journal of Soil Science or Geoderma (both of impact factor of 2.3; year 2013). In fact, microorganisms in terrestrial environments and their assessment of environmental quality are among the priority scopes that were emphasized by the Institute of Chemical Technology (ICT), Prague (Filip and Demnerova, 2009). Several educators are calling for a research-driven microbiology laboratory with innovative and pedagogicallyfascinating nature (Rasche, 2004). Indeed, designing discoverydriven laboratory curricula has been strongly recommended by the National Research Council (2002) to improve undergraduate training for future biological research scientists. Engaging students in research-oriented laboratory courses will allow them to become emotionally attached to their work, which ultimately optimizes their thinking performance towards research oriented mindset (Stahelin et al. 2003; Yeoman \& Zamorski, 2008). Weis (1992) emphasized earlier on the need for B.Sc. curricula that possess analytical and problem solving skills based on critical thinking. Stahelin et al. (2003) emphasized on the need for problem or project based laboratory courses. Project-based practicals captivate student's curiosity and entrain them to research the concepts and principles they need to know (Allen, 1997).

In this paper, we present a novel model of an undergraduate project-oriented laboratory curriculum in environmental soil microbiology. Our laboratory model takes into consideration three teaching integrated sessions including "skill learning", "skill experience" and "an extended problem solving tasks" as previously proposed by Meester and Maskill (1995). Topics of environmental concern were incorporated into our curriculum, not only due to the nature of the subject matter of the course, but also because environmental soil-connected issues is the area of current research interests (Hartemink \& McBratney, 2008), and due to the high level of student interest in environmental problems (Fennessy et al. 1992). Scientific literature and writing skills - yet other important components of learning by inquiry (Wood, 1996) that enhance knowledge acquisition and cognitive skill development in science disciplines (Reynolds et al., 2012) were also considered in our laboratory model and an example of student's scientific final report is presented. The laboratory curriculum was developed by us as a practical part for the environmental soil microbiology (SWAE3411) course and as a component of the undergraduate Soil Sciences program offered by the department of Soil, Water, and Agricultural Engineering at Sultan Qaboos University (SQU) in Oman.

\section{Course Design}

The laboratory curriculum outlined here involves three main components namely the "skill learning", "research experience", and "effective writing skills". In other words, students were initially enriched with basic concepts and laboratory skills in soil microbiology and then assigned a research project that will allow them to grow as a critical thinker with the capability to identify and deal with a scientific problem. The practical schedule was divided in 2 modules (I and II), the first being of 8 weeks in duration and the second of 7 weeks (Table 1). Module I or the "pre-inquiry phase" consisted of basic laboratory concepts, instruments, and techniques in soil microbiology that includes training in how to use volumetric devices (including micro-pipetting devices), light microscopy, contact slide technique, counting using serial dilution, streaking methods, and identification of major groups of soil microbes (i.e. bacteria and fungi). Students were asked to write 4-5 frequent lab reports to demonstrate the type of skills that they have gained from the first module. Module II which is the "inquiry phase" was offered in the form of an addressed research problem with topics relevant to soil-microbesenvironment interactions; using the techniques learnt in module I. This equates to the proposed "skill experience" session and is considered as a typical open-ended laboratory activity where students are given the opportunity to work as independently as possible while the instructor acts as a facilitator in the whole scientific process (D'Avanzo, 1996). The nature of lecture topics taught as a companion with the laboratory modules are shown in Table 1, as weekly scheduled. The lectures were designed to enrich the students with concepts and fundamentals that will help 
Table 1. Weekly course schedule for the Environmental Soil Microbiology course.

\begin{tabular}{|c|c|c|}
\hline Week & Laboratory Exercise & Lecture Topics \\
\hline $\begin{array}{l}\text { Module I } \\
\text { Week } 1\end{array}$ & $\begin{array}{l}\text { Laboratory safety and an introduction to microbiological } \\
\text { tools and equipments }\end{array}$ & Introduction and history of soil microbiology \\
\hline Week 2 & $\begin{array}{l}\text { Introduction and assignment to the research topics and } \\
\text { literature review initiation }\end{array}$ & Microbial growth \& metabolism \\
\hline Week 3 & $\begin{array}{l}\text { Introducing soil sampling, sample preparation, incubation } \\
\text { techniques }\end{array}$ & Soil as microbial habitat (I): Soil texture and structure \\
\hline Week 4 & Contact slide technique, and microscopy and staining & $\begin{array}{l}\text { Soil as microbial habitat (II): Cation exchange capacity, } \\
\text { soil pH, and salinity }\end{array}$ \\
\hline Week 5 & $\begin{array}{l}\text { Contact slide observation for filamentous fungi, bacteria, } \\
\text { and actinomycetes, serial dilution, plating methods, and } \\
\text { counting }\end{array}$ & $\begin{array}{l}\text { Soil as microbial habitat (III): Soil moisture content and } \\
\text { water availability, aeration, and soil temperature }\end{array}$ \\
\hline Week 6 & Culturing and streaking (I) & Exam 1 \\
\hline Week 7 & Culturing and streaking (II) & $\begin{array}{l}\text { Major groups of soil organisms and soil environment (I): } \\
\text { Macro, Meso,-Fauna }\end{array}$ \\
\hline Week 8 & Basic, gram, and spore staining for bacteria and fungi & $\begin{array}{l}\text { Major groups of soil organisms and soil environment (II): } \\
\text { Soil bacteria and actinomycetes }\end{array}$ \\
\hline $\begin{array}{l}\text { Module II } \\
\text { Week } 9\end{array}$ & $\begin{array}{l}\text { Research project (l): Research protocol, experimental } \\
\text { setting up, treatments and soil incubation }\end{array}$ & $\begin{array}{l}\text { Major groups of soil organisms and soil environment (III): } \\
\text { Soil fungi }\end{array}$ \\
\hline Week 10 & Research project (II): Soil incubation and data collection & $\begin{array}{l}\text { Biochemical cycles-Carbon cycle } \& \text { the carbon cycle-soil } \\
\text { organic matter and soil humus decomposition }\end{array}$ \\
\hline Week 11 & & Exam 2 \\
\hline Week 12 & Research project (III): Soil incubation and data collection & $\begin{array}{l}\text { Biochemical cycles-Carbon cycle } \& \text { the carbon cycle-soil } \\
\text { organic matter and soil humus decomposition }\end{array}$ \\
\hline Week 13 & & The nitrogen cycle-forms and transformations \\
\hline Week 14 & Research data analyses & Soil microorganismes and environnemental quality (I) \\
\hline \multirow[t]{2}{*}{ Week 15} & Submission of final report and students presentations & Soil microorganismes and environnemental quality (II) \\
\hline & & Final Exam \\
\hline
\end{tabular}

them for their laboratory activities. Inquiry-type science laboratory should be conducted in the context of, and integrated with, the concepts being taught in class (Mamlok-Naaman et al., 2012). Topics addressed in the lecture were structured such that as the practical exercise progressed, lectures covering a particular experimental part were delivered (see lecture topics in Table 1). The Students were divided into groups (4-5 students per group with one assigned as a leader) and different research projects were assigned to each group. While assigning the different projects, the course instructor has to make sure that all groups will experience the main components of the learning by inquiry as defined above by the NRC (1996). All groups are expected to apply most of the techniques learned from module I during the course of their research investigation. The project assignment was initiated at week 2 to give students enough time for literature search throughout the semester. The following is a typical example of one of the project assignments and final technical reports expected from the students.

\section{Project Assignment and Final Report (Example)}

\section{a. Project Assignment}

The main objective was to investigate the possible effects of two of the most commonly used pesticides by local farmers and their application rate on microbial activities. After the submission of a research protocol, students were responsible for initiating and setting up of experiment, soil incubation and treatments, and data collection and analyses. Students have to implement the necessary techniques and skills gained from module I. Finally, student's task was to write a scientific final report as an important outcome that improve communication and enhance reasoning and organization capabilities of undergraduate education (Ryan \& campa, 2000). The following is an example of the final technical report expected from the students.

\section{b. Final Report}

\section{Introduction}

Pesticides are defined as substances that are used to kill, control, prevent or moderate pests, regulate plant growth, increase crop productivity and others (Aktar et al. 2009). Pesticides include fungicides, rodenticides, herbicides, mollucicides and germicides. Over the past 50 years, a wide range of pesticides with different chemical formulas have been used increasingly in the soil environment (Johnsen et al. 2001). Over usage of these chemical, under the philosophy "if little is good, a lot more will be better", has played havoc with human and other life forms (Aktar et al. 2009). Currently, there is a concern on the 
widespread use of pesticides on agricultural soils due to their possible effects on microbial diversity, activities, and function (Greaves, 1982; Lynch, 1995; Digrak \& Özçelik, 1998). In addition, extensive use of pesticides in agro-ecosystem may impact the catabolic role of soil microbes on the global cycling of elements such as carbon, nitrogen, phosphorous and others through decomposition of plants and animals residues (Pandy \& Sing, 2004). Pesticides may suppress the growth of some soil microbial communities while proliferate others that ultimately disturbs the ecological niches of the soil environment (Johnsen et al. 2001). In fact, this type of disturbance in the microbial diversity of the soil ecosystem may reduce the capacity of soils to suppress soilborne plant diseases and therefore reduce the "health" status of a soil (van Elsas et al. 2002). Therefore there is a need of a strict regulation and guidelines prior the approval of new pesticides. Specifically, their effects on microbial processes should be measured (() European Communities, 2007). Bacteria and fungi are among two most important groups of soil microbes. Bacteria are unique in terms of their diversity, abundance (106 to 1014 $\mathrm{g}^{-1}$ soil, and their adaptation to life in extreme soil environments (Brady \& Weil, 2007). Fungi have a major contribution of the microbial biomass (up to $2,500 \mathrm{~kg} \mathrm{ha}^{-1}$ ) and are the primary agents of organic matter decay. (Killham, 1994; Coyne, 1999). Our research project was to study the overall effects of two types of pesticides and their application rates on microbial growth and types. Bacteria and fungi were the main groups of microbes considered for this study.

\section{Material and Methods}

A soil sample was collected from the Agriculture Experiment Station, Sultan Qaboos University, Oman (latitude $35^{\circ} 7^{\prime} \mathrm{N}$, longitude $20^{\circ} 56^{\prime} \mathrm{E}$, altitude $7 \mathrm{~m}$ ) and basic soil physicochemical analyses was conducted. The collected soil sample was sieved $(2 \mathrm{~mm})$ and stored at $4{ }^{\circ} \mathrm{C}$ prior to incubation and treatments. The two types of pesticides used for this project were Decis ${ }^{\circledR}$ Forte (Deltamethrin) and Acute ${ }^{\circledR}$ Confidor (imidacloprid-N-methyl pyrrolidone) with a chemical formula of $\mathrm{C}_{22} \mathrm{H}_{19} \mathrm{Br}_{2} \mathrm{NO}_{3}$ and $\mathrm{C}_{9} \mathrm{H}_{10} \mathrm{CIN}_{5} \mathrm{O}_{2}$, respectively. The stored soil sample was divided into three portions each weighing $200 \mathrm{~g}$ and two different rates of the two pesticides were applied (maximum usage rate 0.50 $\mathrm{mL} \mathrm{L}^{-1}$, and $10 \%$ extra usage rate, $0.55 \mathrm{~mL} \mathrm{~L}^{-1}$ ) to the two soil portions while no pesticide was applied to the third portion, a control. The samples were incubated at the field capacity soil moisture content $(\theta \mathrm{m}=20 \%)$, at room temperature, in $0.025 \mathrm{~mm}$ thickness Ziploc ${ }^{\circledR}$ bags (Al-lsmaily \& Walworth, 2008), and for five weeks. Microbial data were collected occasionally during the five weeks of the incubation period (i.e. week 1, 2, 4, and 5). Bacteria and filamentous soil fungi were isolated, observed, quantified as a colony forming unit (cfu) by using dilution and plating techniques (Maier et al. 2000; Pepper \& Gerba, 2004). Pure culturing, wet mount staining for fungi, and gram staining for bacteria analyses were also conducted (Pepper \& Gerba, 2004).

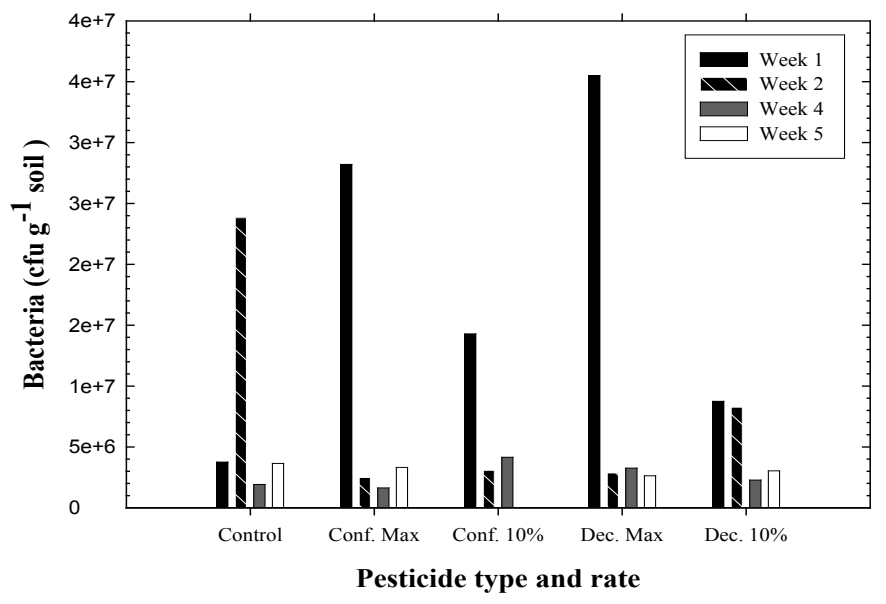

Figure 1. Effect of pesticide type and rate on bacteria population.

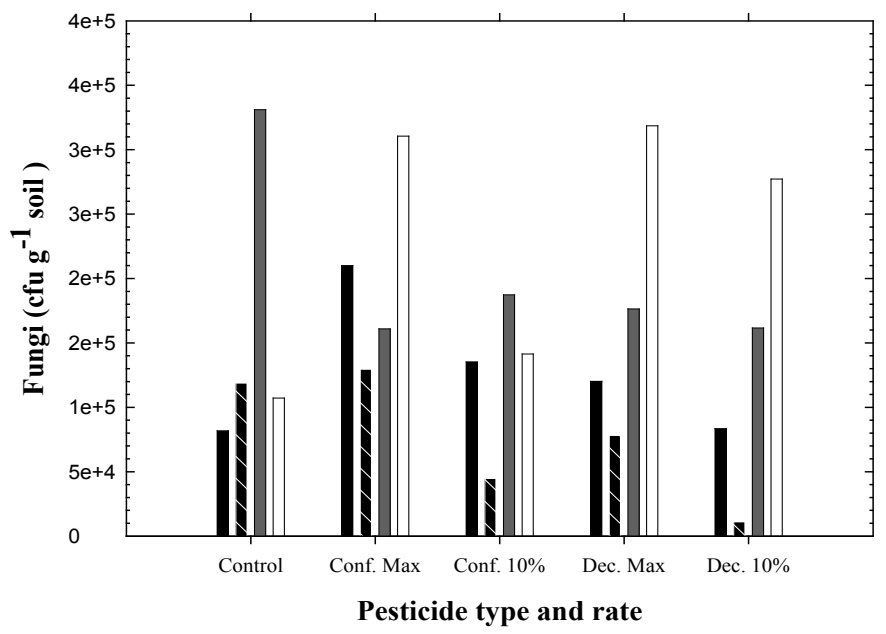

Figure 2. Effect of pesticide type and rate on fungi population.

\section{Results and Discussion}

The soil used for this study was loamy sand with $\mathrm{pH}=8.9$, ECe $=1.1 \mathrm{dS} \mathrm{m}$, total soil $\mathrm{N}=1.2 \mathrm{~g} \mathrm{~kg}^{-1}$, and basic cations $\mathrm{Ca}, \mathrm{Mg}, \mathrm{Na}$, and $\mathrm{K}$ of $12.3,3.8,18.3$, and $27.6 \mathrm{mg} \mathrm{kg}^{-1}$; respectively. The cfu for bacteria and fungi during the incubation period is shown in Figures 1 and 2; respectively. As of weeks 1-2 and for the control, bacterial counts were in the order of 105-107 $\mathrm{cfu} \mathrm{g}^{-1}$ of soil while fungal counts were in the order of 104-105 cfu g of soil, as reported by Brady and Weil (2007) and Ogunmwonyi et al. (2008). Generally speaking, bacteria were initially more impacted by the pesticides than fungi and the latter were quicker in recovering over time (Figs. 1 and 2; respectively). Furthermore, pesticides observed to stimulate the growth of fungi as of weeks 4-5 (Fig. 2 and Fig. 3ab) while there was a relatively more inhibition or a static in stimulation in bacteria growth with time (Fig. 1). The same results were reported by Xu and Zhang (1997) and Pandey and Singh (2004). In contrary, Glover-Amengor and Tetteh (2008) concluded that 


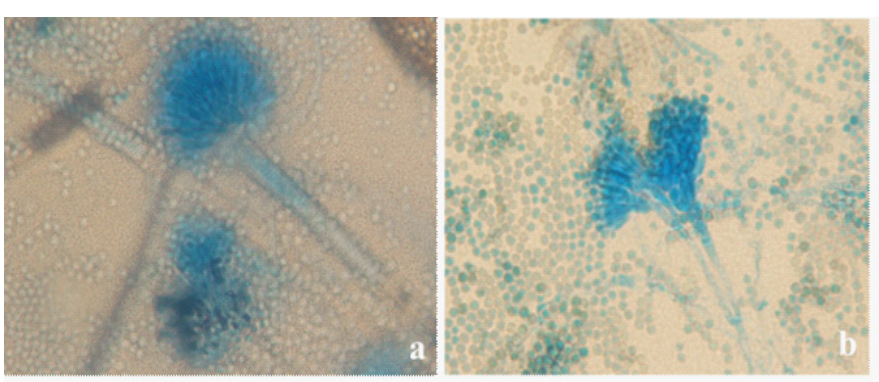

Figure 3. Fungi reproducing asexually by means of conidia as of (a) week 5 compared to (b) week 1 where there were less spreading of the conidia by the conidiophore.
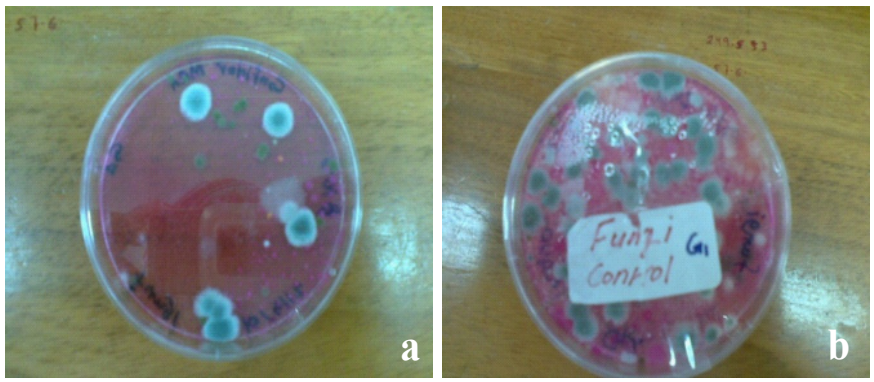

Figure 4. White and green fungi as observed in soils applied with (a) Acute ${ }^{\circledR}$ Confidor and (b) Decis ${ }^{\circledR}$ Forte pesticides.

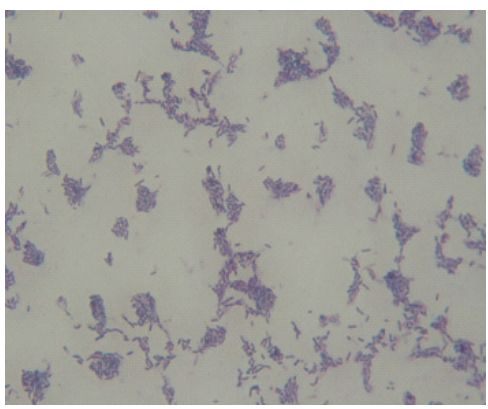

Figure 5. Gram positive bacteria as observed in all treatments.

pesticide application had a higher effect on fungal population $(50-70 \%$ reduction) than on bacterial population in the soil (23.0-38.4\% reduction). Obviously, these contradictions in results may be due to variation in the nature and chemical formula of pesticides used for the different studies (Diallo, 1986). Over application, as compared with the recommended dose, the "extra dose" of both pesticides has resulted in an overall lower microbial population for both groups (Figs. 1 and 2). The residual effects and toxification capacity of a pesticide to soil microbes is increased with higher dosages (Bliev et al. 1985). In further progress of this project, it has been observed a type of white fungi that were more common in soils added the Acute ${ }^{\circledR}$ Confidor pesticide where a green type of fungi were the domi- nate in both the control and samples applied with the Decis ${ }^{\circledR}$ Forte pesticide (Figs. 4ab). Several studies have identified certain types of soil microbes that are responsible for degradation of individual pesticides (Cahudhry \& Wheeler, 1988; Digrak \& Özçelik, 1998). Depending on the type, pesticides influence the diversity of soil microbes (Brady \& Weil, 2007). As far as the type of bacteria is of concern for this study, only gram positive types were observed (Fig. 5).

\section{Summary}

This study shows that estimation of a soil microbial group, in terms of their growth and diversity, might be useful to assess the possible side effects of pesticides in the soil ecosystem. Our result showed that the bacteria and fungi microbial communities responded differently to the two pesticides used. The type of pesticide may enhance the growth of specific types of soil microbes in expense to others. Over application of pesticides had more inhibitory effects on the microbial communities investigated during this study.

\section{Assessment Strategy}

In order to assess student's achievements and progress in the acquisition of the "skill learning", "research experience", and "effective writing skills" components, three assessment tools were developed. The assessment tools consisted of the (i) "frequent" students reports and progress report by the group leader, (ii) teacher and technical staff observations of the individuals in each group, and (iii) final achievements which is reflected through student's final report and their performance during the oral presentation. With Module (I) activities that include the basic laboratory techniques and submission of the "frequent" reports, these were used to evaluate student's progress and performance in gaining the necessary skills such as ability to use a particular piece of apparatus, follow a protocol controls and safety, observe and record accurately, process data, use statistical methods, and present data, results, conclusions. Student's acquisition from the "research experience" or Module (II) was evaluated based on activities such as asking relevant questions, hypothesizing, choosing a question for further investigation, planning an experiment, conducting the experiment (including observations) and finally analyzing the data and arriving at conclusions. Students' performance during their oral presentation was one of the key factors used for the assessment of students thinking and metacognitive abilities gained from their research. Metacognitive abilities are of significantly important in fostering student's research skills (Zion et al., 2005). The final report, as shown above, was evaluated based on the findings in the literature, method description, results communication, data explanation and reasoning, and nature of outcomes. The report was used as a measure to determine the effectiveness of transforming students from thinking about science as a collection of facts to be memorized towards a deeper understanding of concepts and scientific ways of thinking (i.e. the ability in studying and understanding soil microbes in context, rather than in isolation). 


\section{Students Feedback}

Students of different cohorts used to evaluate this research driven laboratory part of "environmental soil microbiology" course by responding to the standard teacher evaluation given at Sultan Qaboos University. The overall rating for the instructor in the laboratory section was $3.75,3.95,3.73,3.76$, and 3.80 out of 4.00 points as of 2009-2013. In a separate written survey, when students asked about the best they liked about the course, the majority expressed their appreciation and enjoyment in terms of the type of skills, knowledge, and team-work ethics that they have gained after the accomplishment of the projects assigned.

\section{Conclusions}

Improve laboratory curricular materials in environmental soil microbiology education towards research-driven is a must more than ever as the world is facing new types of problems associated with new manipulated and/or emerging soil environments and as due to the multiple functions of soil microbes in the terrestrial ecosystems.

Our multifaceted research-oriented laboratory course was designed in line with the five essential components of the scientific inquiry system as defined by the NRC (1996). The inquiry-based approach used for the course provides studnets an opportunity to learn and experience science with greater understanding and enables students to practice their metacognitive abilities. The pedagogy of our laboratory course provides a good opportunity- for undergraduates in soil or other natural sciences- in promoting critical thinking, making predictions, proposing causative factors, and presenting consistent arguments to support a position through effective scientific writing which ultimately we anticipate to play a major role towards their future carrier. Student's perception on our research-oriented laboratory curricula was positive and we were able to captivate their curiosity as reflected by the high students' evaluation scores (avg. 3.8 out of 4.0; based on five years data) and their comments from the written survey. The curricula presented in this study can be used as a template, with minor modification depending on the subject matter, by others instructors in science as it integrate the three main pillars (i.e. skill learning, research experience, and effective writing skills) that advocate learning by inquiry and cognitivity.

\section{Acknowledgments}

The authors would like to thank the undergraduate students at the department of Soil, Water \& Agricultural Engineering at SQU for their contribution. Also, special thanks to Prof. Anvar kacimov at SQU for his comments while reviewing the manuscript of this work.

\section{References}

Aktar W, D Sengupta, and A Chowdhury (2009) Impact of pesticides use in agriculture: Their benefits and hazards. Interdisciplinary Toxi- cology 2 (1): 1-12.

Al-Ismaily S and JL Walworth (2008) Effects of osmotic and matric potentials on nitrogen mineralization in unamended and manureamended soils. Soil Science 173 (3): 203-213.

Allen DE (1997) In: AP McNeal, CD' Avanzo (eds.) Student-active science. Saunders College Publishing, New York, pp. 259-275.

American Association for the Advancement of Science (1989) Project 2061, Science for all Americans, Washington, DC.

Bates GR (1978) The role of the laboratory in secondary school science programs. In: MB Rowe (ed.) What research says to the science teacher, Vol. 1. Washington D.C: National Science Teachers Association.

Bliev U K, AN Martynov, AV Zarkov, and LI Maximova (1985) Effect of verpa preparation on the fertility of soddy podzolic soil. Agrochimica (2): 97-100.

Brady NC and RR Weil (2007) Elements of the nature and properties of soils. Pearson Education, Inc., Upper Saddle River, New Jersey USA.

Bransford JD, A Brown, and R Cocking (1999) How people learn: Mind, brain, experience, and school. Washington, DC: National Research Council.

Bruck AD and M Towns (2013) Development, implementation, and analysis of a national survey of faculty goals for undergraduate chemistry laboratory. Journal of Chemical Education 90 (6): 685-693.

Chaudhry GR and WB Wheeler (1988) Biodegradation of carbamates. Water Science and Technology (20): 89-94.

Coyne MS (1999) Soil microbiology: an exploratory approach. Delmar Publisher, Albany, New York.

D'Avanzo C (1996) Three ways to teach ecology labs by inquiry: guided, open-ended, and teacher-collaborative. Bulletin of the Ecological Society of America 77 (2): 92-93.

Diallo A (1986) Insecticides and the environment (References to tropical environment). Ecosystem management in developing countries. UNEP Postgraduate Training Course on Eecosystem Management. Technical University of Dresden GDR.

Digrak M and S Özçelik (1998) Effect of some pesticides on soil microorganisms. Bulletin of environmental contamination and toxicology 60 (6): 916-922.

European Commission (2007) EU Policy for a Sustainable Use of Pesticides: The Story Behind the Strategy. European Commission.

Fennessy MS, GK Sims, and SR Kehrmeyer (1992) A model laboratory system for teaching concepts important in soil microbiology. Journal of Natural Resources and Life Science Education 21: 79-83.

Filip Z and K Demnerova (2009) Education in microbiology as a tool to meet challenges of environmental security. In: Addressing global environmental security through innovative educational curricula. Springer Netherlands. (pp. 205-214)

Glover-Amengor M and FM Tetteh (2008) Effect of pesticide application rate on yield of vegetables and soil microbial communities. West African Journal of Applied Ecology (12): 1.

Greaves MP (1982) Effect of pesticides on soil microorganisms. In: RG Burns, JH Slater (eds.) Experimental microbial ecology. Blackwell, Oxford, pp. 613-630.

Gunstone RF and RT White (1981) Understanding of gravity. Science Education 65, 291-299.

Hartemink AE and AB McBratney (2008) A soil science renaissance. Geoderma 148: 123-129.

Hodson D (1993) Re-thinking old ways: towards a more critical ap- 
proach to practical work in school science. Studies in Science Education 22: 85-142.

Hofstein A, O Navon, M Kipnis, R Mamlok-Naaman (2005) Developing students' ability to ask more and better questions resulting from inquiry-type chemistry laboratories. Journal of research in science teaching 42 (7): 791-806.

Hofstein A and VN Lunetta (2004) The laboratory in science education: Foundations for the twenty-first century. Science education 88 (1): 28-54.

Hopmans JW (2007) A plea to reform soil science education. Soil Science Society of America Journal (71): 639-640.

Johnsen K, CS Jacobsen, V Torsvik, and J Sørensen (2001) Pesticide effects on bacterial diversity in agricultural soils-a review. Biology and Fertility of Soils 33 (6): 443-453.

Killham K (1994) Soil ecology. Cambridge, England: Cambridge University Press. UK.

Kotiw M, RP Learmonth, and MW Sutherland (1999) Biological methods: a novel course in undergraduate biology. Biochemical Education 27: 131-134.

Lin H. (2006) In: AEH (ed.) The future of soil science. Wageningen: International Union of Soil Sciences, pp. 80-83.

Lynch MR (1995) Procedures for assessing the environmental fate and ecotoxicity of pesticides. Society of Environmental Toxicology and Chemistry Brussels, Belgium.

Maier RM, IL Pepper, and CP Gerba (2000) Environmental Microbiology. Academic Press, San Diego.

Mamlok-Naaman R and B Nitza (2012) Laboratory activities in Israel. Eurasia Journal of Mathematics, Science \& Technology Education 8: 49-57.

Meester MAM and R Maskill (1995) First-year chemistry practicals at universities in England and Wales: aims and the scientific level of the experiments. International Journal of Science Education 17 (5): 574-558.

National Research Council (1996) National science education standards. Washington, DC: National Academy Press.

National Research Council of the National Academies (2002) BIO2010: Transforming Undergraduate Education for Future Research Biologists, National Academies Press, Washington, DC.

Ogunmwonyi IN, OE Igbinosa, OA Aiyegoro, and EE Odjadjare (2008) Microbial analysis of different top soil samples of selected site in Obafemi Awolowo University, Nigeria. Scientific Research and Essay 3 (3): 120-124.

Pandey S and DK Singh (2004) Total bacterial and fungal population after chlorpyrifos and quinalphos treatments in groundnut (Arachis hypogaea L.) soil. Chemosphere 55 (2): 197-205.

Pepper IL and CP Gerba (2004) Environmental microbiology: A laboratory manual, 2nd Edition. Elsevier Science/Academic Press. San Diego, CA.

Rasche ME (2004) Outcomes of a research-driven laboratory and literature course designed to enhance undergraduate contributions to original research. Biochemistry and Molecular Biology Education 32:
101-107.

Reynolds JA, C Thaiss, W Katkin, and RJ Thompson (2012) Writingto-learn in undergraduate science education: A community-based, conceptually driven approach. CBE-Life Sciences Education 11 (1): 17-25.

Russell CB and GC Weaver (2008) Student perceptions of the purpose and function of the laboratory in science: a grounded theory study. International Journal for the Scholarship of Teaching and Learning 2 (2).

Ryan M R and H Campa (2000) Application of learner-based teaching innovations to enhance education in wildlife conservation. Wildlife Society Bulletin 168-179.

Singer MJ and BP Warkentin (1996) Soils in an environmental context: An American perspective. Catena 27: 179-189.

Skoumios, Michael, and N Passalis (2013) Students' interaction and its relationship to their actions and verbalized knowledge during chemistry labwork. Creative Education 4 (1): 1-8.

Stahelin RV, RE Forslund, DJ Wink, and W Cho (2003) Development of a biochemistry laboratory course with a project-oriented goal. Biochemistry and Molecular Biology Education 31: 106-1 12.

Tiedie JM, JC Cho, A Murray, D Treves, B Xia, and J Zhou (2001) Soil teeming with life: New frontiers for soil science. In: RM Rees, BC Ball, CD Campbell, and CAWatson (eds.) Sustainable management of soil organic matter. CAB International, Wallingford, pp. 393-412.

Tobin KG (1990) Research on science laboratory activities; in pursuit of better questions and answers to improve learning. School Science and Mathematics 90: 403-418.

Weis JS (1992) Undergraduate environmental science report. Environmental Science \& Technology 265:1296-1297.

Wilkinson JW and M Ward (1997) The purpose and perceived effectiveness of laboratory work in secondary schools. Australian Science Teachers Journal, 43 (2): 49-55.

Van Elsas JD, P Garbeva, and J Salles (2002) Effects of agronomical measures on the microbial diversity of soils as related to the suppression of soil-borne plant pathogens. Biodegradation, 13 (1): 29-40.

Wood EJ (1996) Laboratory work in biochemical education: purpose and practice. Biochemical Education, 24 (3): 132-137.

$X \cup B$ and $Y$ Zhang (1997) Environmental behavior of crop protection chemicals. In: Proceeding of an International Symposium on the use of Nuclear and Related Techniques for Studying Environmental Behavior of Crop Protection Chemicals, FAO/IAEA, July 1-5, 1996.

Yeoman KH and B Zamorski (2008) Investigating the impact on skill development of an undergraduate scientific research skills course. Bioscience Education, 11 (5).

Yli-Halla M (2006) In: AEH (ed) The future of soil science. Wageningen: International Union of Soil Sciences, pp. 153-154.

Zion M, T Michalsky, and ZR Mevarech (2005) The effects of metacognitive instruction embedded within an asynchronous learning network on scientific inquiry skills. International Journal of Science Education 27 (8): 957-983. 